\title{
IMPACTS OF SKI PISTES PREPARATION AND SKI TOURISM ON VEGETATION
}

\author{
LÝDIA KŇAZOVIČOVÁ ${ }^{1}$, SILVIA CHASNÍKOVÁ², JÁN NOVÁK ${ }^{3}$, PETER BARANČOK ${ }^{2}$ \\ ${ }^{1}$ Faculty of Natural Sciences, Constantine the Philosopher University in Nitra, Tr. Andreja Hlinku 1, 94974 Nitra, \\ Slovak Republic; e-mail: lydia.knazovicova@ukf.sk \\ ${ }^{2}$ Institute of Landscape Ecology, Slovak Academy of Sciences, Štefánikova 3, 814 99, Bratislava, Slovak Republic; e- \\ mail: chasnikova.silvia@gmail.com; peter.barancok@savba.sk \\ ${ }^{3}$ Faculty of Agrobiology and Food Resources, Slovak University of Agriculture in Nitra, Tr. A. Hlinku 2, 94976 Nitra, \\ Slovak Republic; e-mail: jan.novak@uniag.sk
}

\begin{abstract}
Kňazovičová L., Chasníková S., Novák J., Barančok P.: Impacts of ski pistes preparation and ski tourism on vegetation. Ekológia (Bratislava), Vol. 37, No. 2, p. 152-163, 2018.

Vegetation of the ski slopes in the Low Tatras National Park in Slovakia was evaluated through the environmental variables and species composition caused by human impact assessment. We compared the grasslands located on pistes, off pistes and on the edge of pistes, and within these we also recorded the grassland management. The results show that the majority of study areas managed by transport of sod clippings has reached the lowest number of species; contrariwise, the grasslands with no management are characterized by the highest number of species. Areas on pistes managed by cutting correlates positively with the bare ground. Cover of mosses positively correlates with the total cover and areas with no management. Total of 17 synanthropic plant species and 2 nonnative species as the indicator of human interventions were noticed. They occurred particularly on the edge areas but also in the surroundings of the off piste areas.
\end{abstract}

Key words: vegetation composition, ski slopes, human influence, management.

\section{Introduction}

All human interventions have a strong impact on mountain ecosystems resulting in the destruction of vegetation cover (Wipf et al., 2005), massive changes in soil structure and texture (Ruth-Balaganskaya, Myllynen-Malinen, 2000; Rixen et al., 2003) and threat to the regime of surface and underground water resources (Rixen et al., 2003, 2008). Landscape change is a potentially serious threat to the conservation of the habitats of native species (Rolando et al. 2007), when vegetation reacts with the decrease in biodiversity (Rixen et al., 2003; Wipf et al., 2005; Halabuk et al., 2013), leading to an interruption of successional stages (Urbanska, Fattorini, 2001) and the areas with lack of vegetation cover are likely to be eroded (Ruth-Balaganskaya, Myllynen-Malinen, 2000; Graiss et al., 2005; Barni et al., 2007). The final results are disturbed habitats and non-attractive alpine landscape for tourism which needs to be restored using appropriate management. The environmental damage causes economic losses 
not only in terms of the cost of restoration measures, but also a decline of interest in tourism in the affected areas (Rixen et al., 2003, 2008).

In the Slovak mountains, human interventions started centuries ago, when the Wallachian colonisers, in the $13^{\text {th }}$ and $14^{\text {th }}$ century, have been changing and destroying the vegetation cover by grazing of cattle and sheep, reducing the upper limit of forests, burning mountain pine and making forest clearings in mountain and alpine areas (Midriak, 1983). Nowadays, these undesirable activities are mainly represented by tourism (Piscová, 2011), construction of sports and relaxation facilities and intense construction of ski lifts and ski pistes (Midriak, 1983; Kizeková et al., 2008). All of these activities require considerable demands on environment of mountain landscape (Kizeková et al., 2008).

Winter tourism today represents one of the most important economic sectors in a great part of the world mountains areas (Elsasser, Messerli, 2001; Rixen et al., 2003). At the same time, the impact of ski runs and other infrastructures related to winter sports may have dramatic effects on the fragile mountainous environments (Argenti, Ferrari, 2009; Pohl, 2009). Construction and winter preparation of the ski pistes by machine grading and increased use of artificial snow are considered as the major factors of environmental degradation in the high-elevation ecosystems (Rixen et al., 2003; Ruth-Balaganskaya, Myllynen-Malinen, 2000; Wipf et al., 2005).

Studied area Jasná Nízke Tatry is a very important ski and tourist centre in the Low Tatras National Park, central Slovakia. History of the first ski pistes in these areas dates back to the 50 's of the $20^{\text {th }}$ century (Kulhánek, 1989).

As the destructive impacts on vegetation and soil cover have been very intense in the last couple of years, we decided to summarize the results of our two-years research to analyse the vegetation composition and diversity, compare vegetation composition of ski pistes and the vegetation sampled next to ski pistes or off the ski pistes.

\section{Material and methods}

\section{Field data}

Total of 94 phytosociological relevés (using 24-30 $\mathrm{m}^{2}$ plots), based on the standard methods of Zürich - Montpellier school (Braun-Blanqet, 1964), following the modified 9-point Braun-Blanqet cover-abundance scale (Van den Maarel, 1988), were sampled in the montane up to the alpine zone. We focused mostly on grassland habitats, forest plant communities were not surveyed. The relevés were sampled in the areas of three types of positions - directly on the ski piste, on the edge and off piste. Moreover, within each relevé, the method of management (cutting, a combination of cutting and seeding and transport of sod clippings) was recorded in the subalpine and alpine zones. The only off piste subalpine and alpine grasslands and some of the edge grasslands (mainly monotonous plant communities with the dominance of Rumex alpinus) were treated with no management.

\section{Data analysis}

Before the processing, all relevés were stored into the database program TURBOVEG (Hennekens, Schaminée, 2001). For further modification and analysis, the data were exported to the program JUICE (Tichý, Holt, 2002).

CANOCO 5.0 program (ter Braak, Šmilauer, 2012) was used to analyse the relationships between species composition and environmental variables. Length of gradient was 4.05 using DCA (detrended correspondence analysis), which indicated the use of unimodal method CCA (canonical correspondence analysis) in the next step. Nomenclature of taxa was unified by the Checklist of non-vascular and vascular plants of Slovakia (Marhold, Hindák, 1998). 
Statistica 7 (Statsoft, 2005) was used to describe the selected environmental factors of the data set in this study. Box plots were used to evaluate and compare the differences of variables according to the position at the ski piste and management treatments. Univariate test of significance following one-way ANOVA was used to determinate the significant statistical differences between groups (at a significance level of $p<0.05$ ). Correlations between the variables of data set were processed by the non-parametric Spearman's rank order correlation test.

\section{Study area}

Low Tatras National Park is the largest national park in Slovakia in terms of area. The highest peak is Dumbier (2043 $\mathrm{m}$ a.s.1.). The Low Tatras Mts lie in east-west direction, in the central part of Slovakia (Fig. 1), nearly 100 kilometres in length. The geographical coordinates range within $48^{\circ} 42 »-49^{\circ} 09^{»}$ of the latitude and $19^{\circ} 16 »-20^{\circ} 17$ » of the longitude. The Low Tatras Mts consist of the rocks of Crystalline-Mesozoic zone in the West Carpathians (Lacika, 2001).

The overall character of vegetation is determined by the climatic conditions forming vegetation zones from the submontane up to the alpine zone (Vološčuk, 2005). The original vegetation has been greatly changed due to deforestation and new areas of grasslands and pastures were created. Grassland vegetation of the Low Tatras Mts has been highly valuated for its exceptionally rich diversity (Turis, 2007). Our study was carried out on the ski pistes and the areas near the Jasná Nízke Tatry ski resort (Fig. 1). The ski resort ranges from the second highest peak Chopok to the northern as well as the southern slopes (from $943 \mathrm{~m}$ a.s.l. up to $2004 \mathrm{~m}$ a.s.l.) with average slope up to $40^{\circ}$.

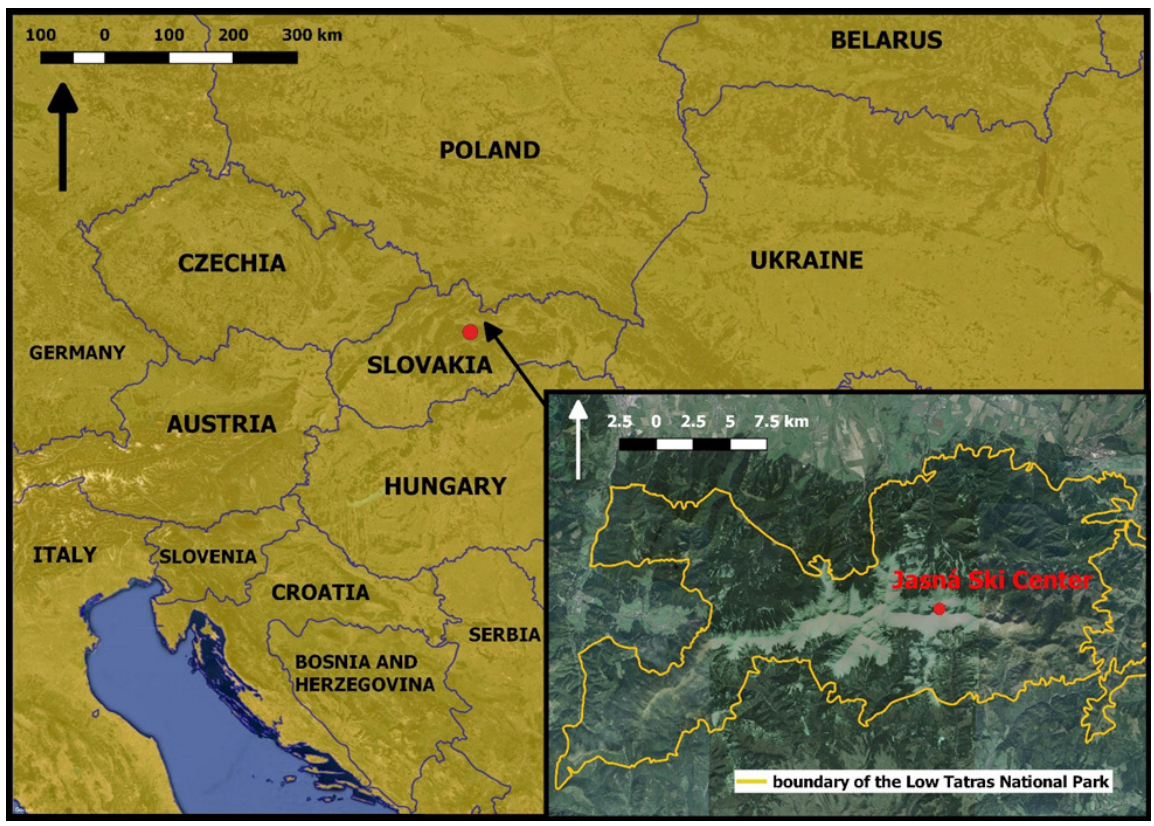

Fig. 1. The map of the study area.

\section{Revegetation}

Soil and vegetation are affected by construction of ski pistes, their preparation and especially snowpack compression, machine grading and levelling, when the vegetation and top layer of soil are being removed and compressed (Kangas et al., 2009; Bjedov et al., 2011). In particular, machine grading for winter sports causes environmental 
degradation such as erosion that has a negative effect on biodiversity. In addition, the common result of these processes is washing out the seeds after repeated rain falls, which prevents the slopes of revegetation (Wipf et al., 2005; Iselin-Nondedu et al., 2007). Vegetation provides protection to the soil and its anti-erosive effect is constant through the whole year. Revegetation of the ski slopes is therefore one of the basic and very important measures that ensures the stability of the mountain landscape and prevents ecological and economic damage. To recover these areas, the degraded ecosystem must be compared with its undisturbed state to determine pre-disturbance soil properties and vegetation cover (Kizeková et al., 2008). The rehabilitation of a disturbed site should aim to minimize the length of time the site is exposed to potential erosion and sedimentation (Behan, 1983; Bjedov et al., 2011), thus rapid reconstruction of the vegetation cover is essential. To establish a stable plant community, it is recommended to use seeds from local natural populations or from species adapted to the disturbed areas using appropriate management methods (Argenti, Ferrari, 2009; Kangas et al., 2009; Bjedov et al., 2011). The preparation of seed mixtures based on the composition of the original vegetation composition is important also because some ski resorts are built within protected areas, national parks and so on, thus preserving the original ecosystems, and prevention of degradation of the original flora has particular importance in these areas (Wipf et al., 2005; Kizeková et al., 2008). In our study area, there are three management methods used for vegetation restoration: 1 - sowing, 2 - aqua sowing, 3 - using jute geotextiles.

\section{Sowing}

Seeds are scattered over the land by hands or by machines and are shallowly $(5-20 \mathrm{~mm})$ incorporated into the soil. This method should be used during windlesness for maximal possible even distribution of seeds (Marhold, Čunderlíková, 1983).

\section{Aqua sowing}

This method of revegetation was created in need of an even distribution of seeds in the large and hard to reach areas. Its application has anti-erosion protection and can be used for the revegetation of slopes up to $60^{\circ}$ even on slopes affected by water or wind erosion. Seeds are mixed with peat, soil and fertilizers and sometimes with anti-erosive substances in the water tanks (Marhold, Čunderlíková, 1983).

Jute geotextiles

The jute geotextile (or coconut geotextile) is unfolded over the ground before the sowing. The geotextile prevents the seeds from being washed away or removed by the wind, while providing them with nutrition. After a while, this geotextile is decomposed (Marhold, Čunderlíková, 1983).

\section{Results}

\section{Results of statistical analysis}

To display the comparison of ecological status of grasslands in consideration of the location to the ski slope and type of management, the box plots were used (Figs 2-7). We focused on the following environmental variables - total cover of vegetation, species richness, Shannon diversity index and synanthropization, while only box plots with statistically significant differences are shown (at a significance level $\alpha=0.05$ ).

When restoring the ski slope, it is important to re-plant the disturbed areas as soon as possible, not only due to esthetical reasons, but also in terms of stability and biodiversity. Sufficiently developed vegetation that covers over $70 \%$ of the soil surface is the only possible way to stabilize the slopes in the long term and reduce soil erosion to an acceptable level (Krautzer et al., 2011). In the Figures 2 and 3, the vegetation cover of study area is represent- 


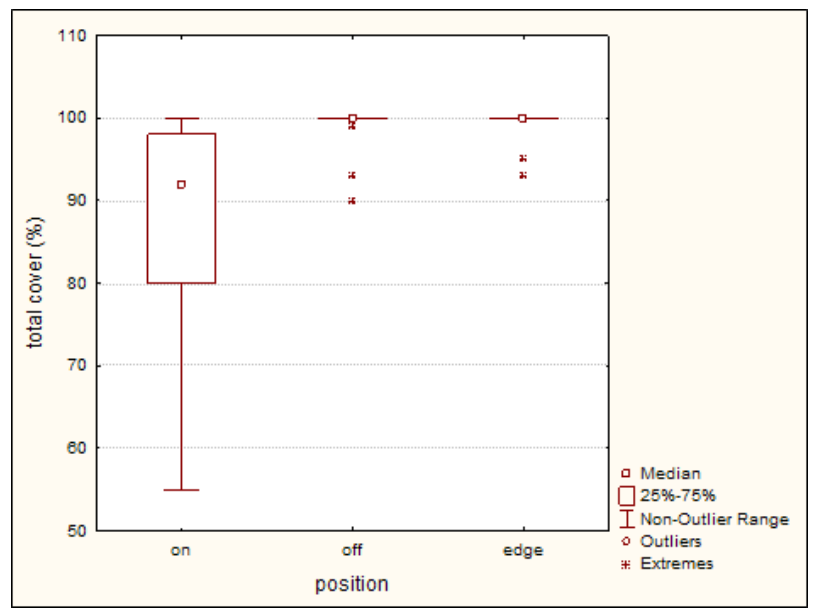

Fig. 2. Box plot of total cover of vegetation in percentage grouped by position on the ski piste.

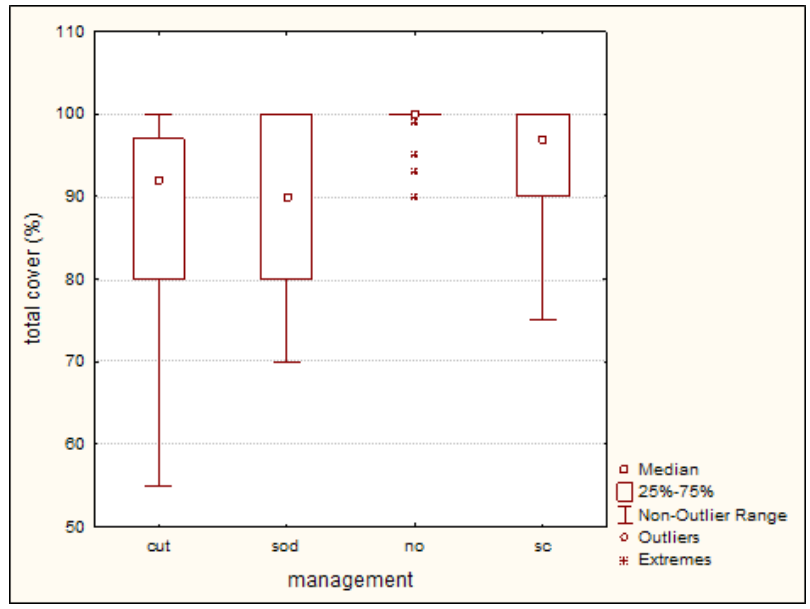

Fig. 3. Box plot of total cover of vegetation in percentage grouped by type of management.

Notes: cut - cutting; sod - transport of sod clippings; no - no management; sc - combination of cutting and seeding. ed. The total vegetation cover varies depending on the type of management of the ski piste, which reflects conditions of the slopes. The off piste grasslands and edge areas, as well as, areas with no management are mostly with $100 \%$ vegetation cover. The combination of cutting and seeding in appropriate conditions (altitude) could turn out as the possibly effective way of management, according to the coverage of vegetation in the study area.

Conditions which occur after the construction and machine grading of ski resorts could result in poor biodiversity and reduced species richness with the following decrease of ecosystem functions (Cole, Bayfield, 1993; Whinam, Chilcott, 2003; Wipf et al., 2005; Rolando et al., 2007; Burt, 2012). In our study, we noticed variances of species richness between the "on" and "off” piste areas (Fig. 4). From areas located directly on piste through the edge to the off piste, the number of species has increased. Variability in species richness on the ski piste reflects the different management practices (Figs 4, 5). The majority of the study areas managed by the transport of sod clippings has reached the lowest number of species; contrariwise, grasslands with no management are characterized by the highest number of species (Fig. 5).

Differences in the Shannon diversity index between areas with different positions on the ski slope and also between the management treatments have not been proven statistically 
significant. In the study area, we also recorded plant species included in The IUCN Red List of Threatened Species in category vulnerable - Crepis conizyfolia and in category of Least Concern Carex bigelowii, C. capillaris, Gentiana punctata, Ranunculus pseudomontanus and Soldanella carpatica (IUCN, 2016).

Acquaintance of occurrence and representation of non-native and synanthropic plant species in the study site is the requisite condition for grassland degradation assessment. Overall, 17 synanthropic plant species and 2 non-native species (Table 1) have been recorded at the ski slopes in the study area. Differences between percentage of occurrence of these species in the grasslands, in consideration of position and implemented management, are displayed in Figures 6 and 7. The lowest ratio of synanthropization was noticed directly on the areas located on ski piste, where the notable species were - Plantago major, Poa annua, Rumex alpinus, Tussilago farfara and Daucus

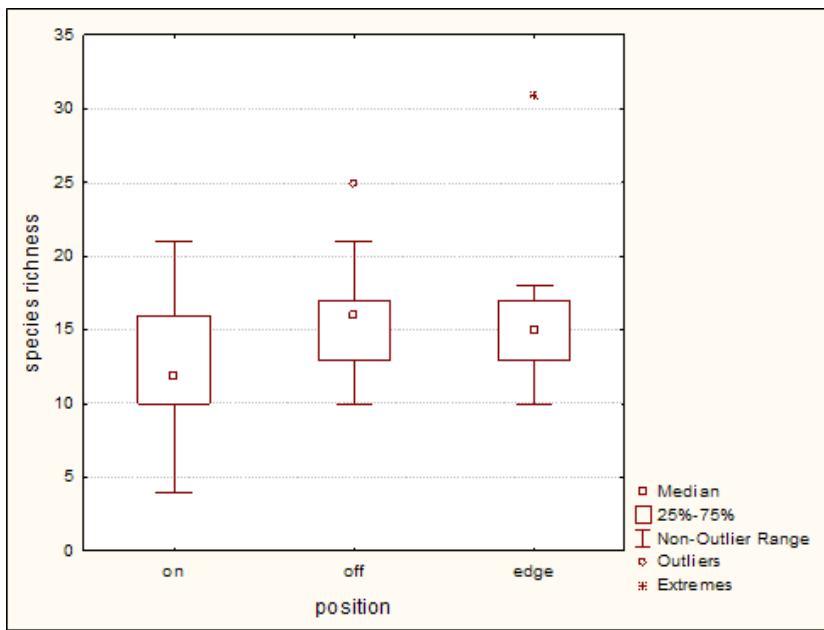

Fig. 4. Box plot of species richness grouped by position on the ski piste.

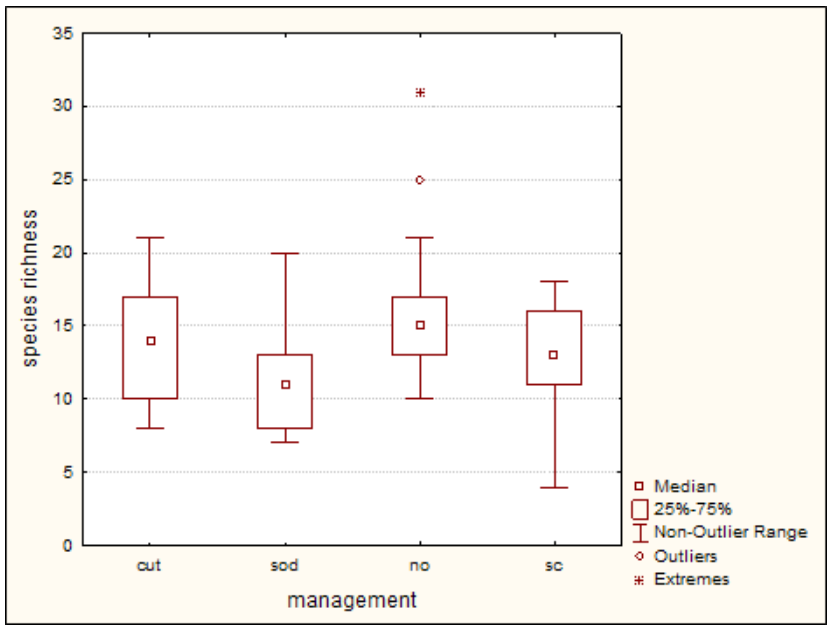

Fig. 5. Box plot of species richness grouped by type of Management.

Notes: cut - cutting; sod - transport of sod clippings; no - no management; sc - combination of cutting and seeding. carota. Some extremes in the spreading of synanthropic species Aegopodium podagraria and Calamagrostis epigejos with high coverage were noticed on the off piste sites, suggesting that anthropically affected are not only the grasslands and trails on the ski slopes but also the surrounding areas. This could also be a result of the management treatments, when species like Rumex alpinus or Aegopodium podagraria are doing 


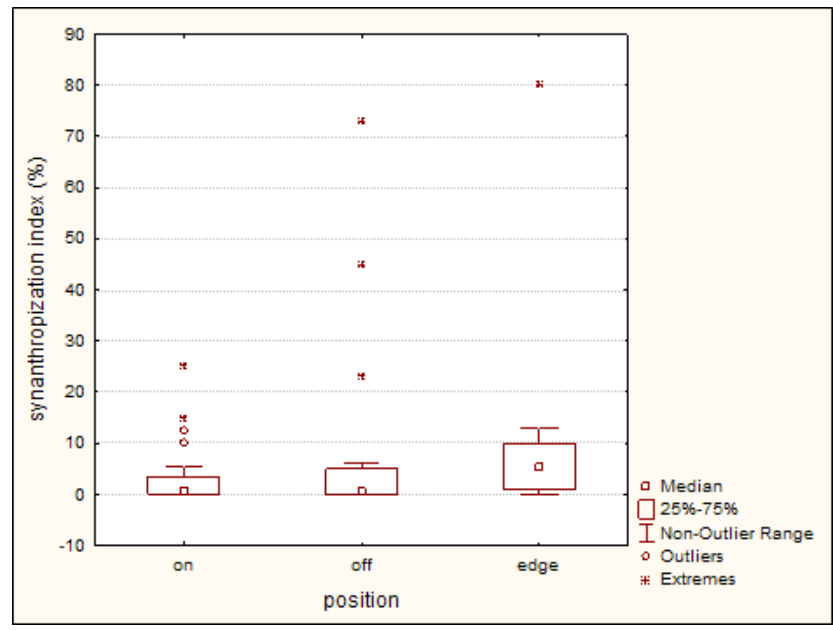

Fig. 6. Box plot of synanthropization index in percentage grouped by position on the ski piste.

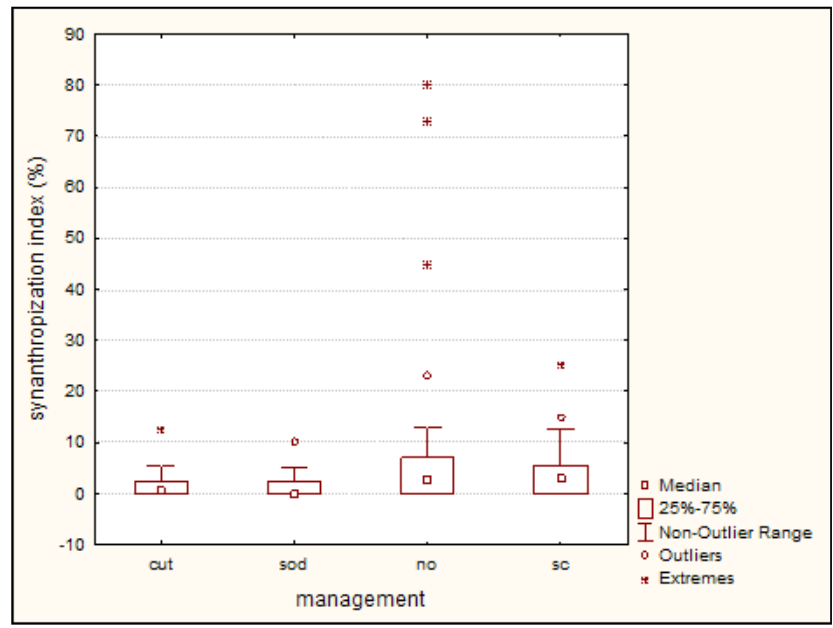

Fig. 7. Box plot of synanthropization index in percentage grouped by type of management.

Notes: cut - cutting; sod - transport of sod clippings; no - no management; $\mathrm{sc}-$ combination of cutting and seeding.

better under no management. Increased percentage of synanthropization on the "edge" areas as compared to the "on" areas is mostly the result of the occurrence of species Poa annua and Urtica dioica. We also noticed the monotonous grasslands there without the management presented by the species Rumex alpinus and Urtica dioica with extremely high coverage up to $65 \%$. This indicates that the soil of these areas contains reserves of phosphorus and
$\mathrm{T}$ a b l e 1. List of plant species included in synanthropization index of study areas.

\begin{tabular}{|l|}
\hline \multicolumn{1}{|c|}{ Synanthropic species } \\
\hline Aegopodium podagraria \\
\hline Calamagrostis epigejos \\
\hline Cirsium vulgare \\
\hline Daucus carota \\
\hline Fragaria vesca \\
\hline Chaerophyllum hirsutum \\
\hline Chamerion angustifolium \\
\hline Plantago major \\
\hline Poa annua \\
\hline Ranunculus repens \\
\hline Rumex alpinus \\
\hline Rumex crispus \\
\hline Stellaria media \\
\hline Taraxacum sect. Ruderalia \\
\hline Tussilago farfara \\
\hline Urtica dioica \\
\hline Veronica chamaedrys \\
\hline Non-native species \\
\hline Lupinus polyphyllus \\
\hline Trifolium hybridum \\
\hline
\end{tabular}


nitrogen, which could be the remains after the construction, presence and high activity of workers.

\section{Results of gradient analysis}

The canonical correspondence analysis (CCA) was used to test relationships between the environmental variables and the floristic composition of the sampled vegetation in the Jasná Ski Centre, Low Tatras Mts. Along with the environmental factors, we wanted to identify how the factors of management and the positions of individual relevés affect the abundance of species and vegetation richness. The tested environmental variables were: Total vegetation cover, Cover of mosses, Elevation, Slope, Bare ground percentage and Potential annual direct irradiation (Figure 8). Similarly, as in the statistical analysis, we also analysed the variables of management used on the ski slopes (cutting; transport of sod clippings; no management; combination of cutting and seeding) and position of the sampled relevés (on, off, edge of the piste).

Some of the typical species for steep slopes and screes and depressions with long lasting snow cover (Juncus trifidus, Carex capillaris, Oreochloa disticha, Soldanella carpatica, etc.) are located along the factors of slope and elevation.

The lower part of the graph belongs to the samples recorded mostly on the edge or off the ski pistes, where no management method was used. As we expected and identically with the statistical analyses, total cover positively correlates with vegetation that is under no management. Species present in this part of the graph (Myosotis scorpioides, Geranium sylvaticum, Dechampsia cespitosa, Alchemilla sp.) are mostly typical for tall herb communities and forests, which have usually very high vegetation cover. Cover of mosses also positively correlates with total cover and areas with no management, as mosses are sensitive to land management and environmental changes (Nelson, Halpern, 2005; Perhans et al., 2009). On the other hand, very few mosses were found in the areas located on ski piste.

T a b l e 2. Spearman rank order correlations between environmental variables

\begin{tabular}{|l|c|c|c|c|c|c|c|c|}
\hline & $\begin{array}{c}\text { Shannon } \\
\text { diversity } \\
\text { index }\end{array}$ & $\begin{array}{c}\text { Species } \\
\text { richness }\end{array}$ & $\begin{array}{c}\text { Total } \\
\text { cover }\end{array}$ & $\begin{array}{c}\text { Synanthro- } \\
\text { pization }\end{array}$ & $\begin{array}{c}\text { Bare } \\
\text { ground }\end{array}$ & $\begin{array}{c}\text { Moss and } \\
\text { lichens }\end{array}$ & Elevation & Slope \\
\hline $\begin{array}{l}\text { Shannon diversity } \\
\text { index }\end{array}$ & 1.000 & & & & & & & \\
\hline Species richness & $\mathbf{0 . 6 8 3}$ & 1.000 & & & & & & \\
\hline Total cover & 0.058 & 0.251 & 1.000 & & & & & \\
\hline Synanthropization & 0.244 & $\mathbf{0 . 3 5 2}$ & 0.281 & 1.000 & & & & \\
\hline Bare Ground & -0.065 & -0.251 & $\mathbf{- 0 . 8 9 1}$ & -0.188 & 1.000 & & & \\
\hline Moss and lichens & -0.031 & 0.2 & 0.121 & -0.247 & -0.183 & 1.000 & & \\
\hline Elevation & -0.189 & -0.259 & -0.069 & $\mathbf{- 0 . 4 3 6}$ & 0.064 & 0.011 & 1.000 & \\
\hline Slope & -0.123 & -0.325 & -0.121 & $\mathbf{- 0 . 3 3 7}$ & 0.088 & 0.001 & $\mathbf{0 . 5 0 5}$ & 1.000 \\
\hline
\end{tabular}

Marked correlations are statistically significant (at level of significance $\mathrm{p}<0.001$ ). 


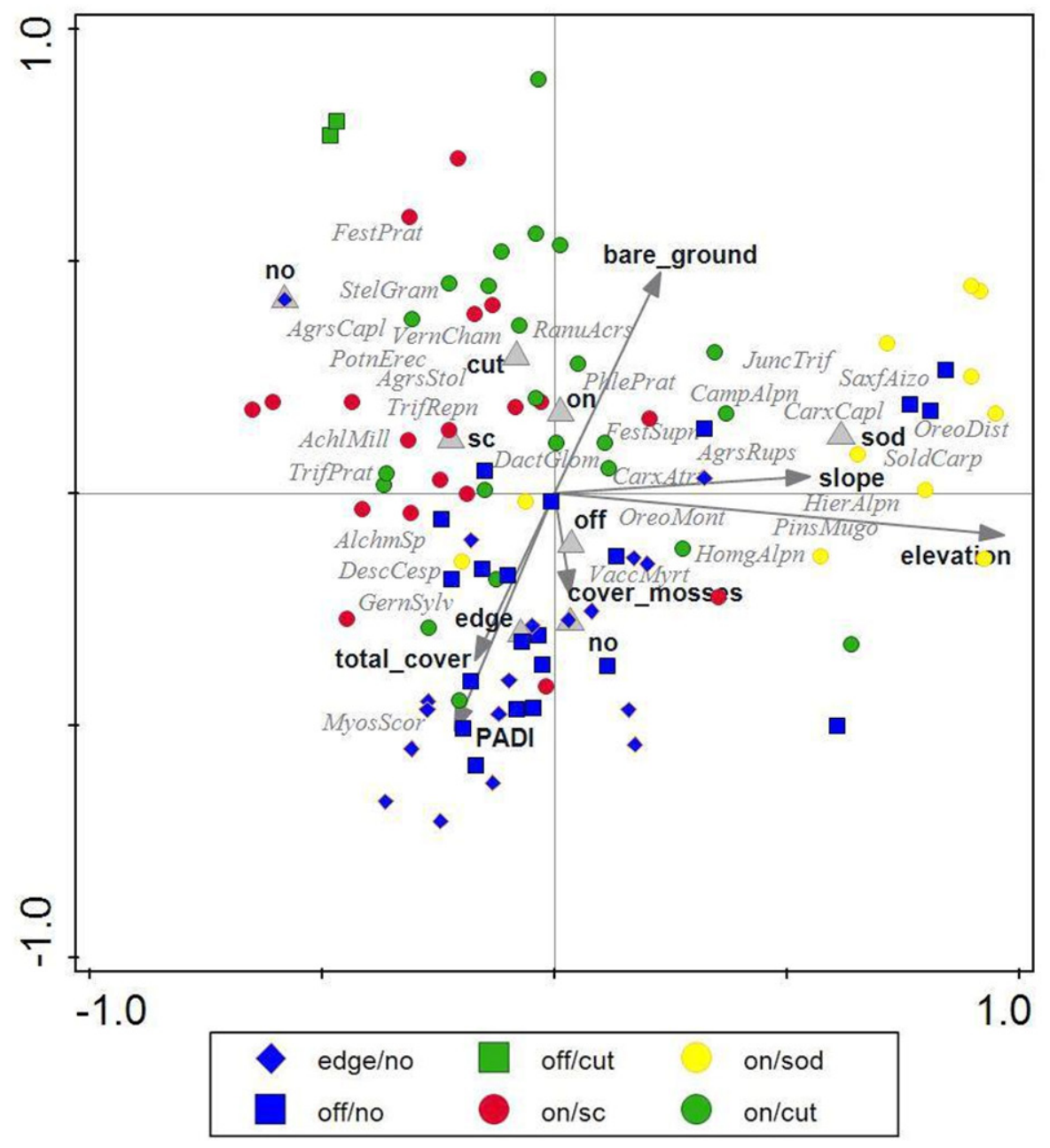

Fig. 8. Canonical correspondence analysis (CCA) ordination diagram of 94 relevés

Notes: cut - cutting; sod - transport of sod clippings; no - no management; sc - combination of cutting and seeding. Abbreviations of the taxa names: AchlMill - Achillea millefolium, AlchmSp - Alchemilla species, AgrsCapl - Agrostis capillaris, AgrsRups - Agrostis rupestris, AgrsStol - Agrostis stolonifera, CampaAlpn - Campanela alpine, CarxAtr Carex atrata, CarxCpl-Carex capillaris, DactGlom - Dactylis glomerata, DescCesp - Deschampsia cespitosa, FestPrat - Festuca pratensis, FestSupn - Festuca supina, GernSylv - Geranium sylvaticum, HierAlpn - Hieracium alpinum, HomgAlpn - Homogyne alpine, JuncTrif - Juncus trifidus, MyosScor - Myosotis scorpioides, OreoDist - Oreochloa disticha, OreoMont - Oreogeum montanum, PhlePrat - Phleum pratense, PinsMugo - Pinus mugo, PotnErec - Potentilla erecta, RanuAcrs - Ranunculus acris, SaxfAizo - Saxifraga aizoides, SoldCarp - Soldanella carpatica, StelGram - Stellaria graminoides, TrifPrat - Trifolium pretense, TrifRepn - Trifolium repens, VaccMyrt - Vaccinium myrtillus, VernCham - Veronica chamaedrys. 
We can see the factor of bare ground in the upper part of the graph, where it correlates negatively with the total vegetation cover. Positively with the bare ground correlates relevés located on ski pistes, which are managed by cutting. Species that are depicted in the upper left part of the graph correspond with the seeding mix used for vegetation restoration (Trifolium repens, T. pretense, Dactylis glomerata, Phleum pretense, Festuca pratensis).

\section{Discussion and conclusion}

Winter sports became very popular in the last decade and with growing popularity, demands for suitable areas also grew. In order to promote not only national, but also international tourism, the construction and modernization of ski centres is needed. According to Bowker et al. (1999), during the years 1995-2000, winter tourism increased about $6 \%$ and it is expected to raise about $122 \%$ during the years $2000-2050$.

Important factors used in ski centres are artificial snow and use of heavy equipment during the levelling and preparation of ski runs. There are already many studies dedicated to the research on the variety of effects on the ecosystems during the construction and management of ski centres. Roux-Fouillet et al. (2011) analysed the research sites located on the ski pistes and compared the vegetation and soil characteristics with the areas located outside the ski slopes. The result of their study was reduced coverage and overall production of vegetation. Similarly, our analyses are showing that the off piste study sites have much higher coverage of vegetation in comparison with sites located on pistes. At the same time, the study sites that are under no management are characterized by the highest vegetation cover with notable presence of mosses and lichens. Moreover, the off piste sites and unmanaged sites, sites partially managed by cutting, has reached the highest number of species.

During the construction and management of ski centres, the traffic also increases and construction of routes and logging roads is required. These became an appropriate means for spreading of invasive and synanthropic species (Müllerová et al., 2011). Invasive species gained status of one of the largest threats to natural ecosystems of conservation and economic sides in recent years. These species may reduce or replace the original species and can also change the functions of the ecosystem (Eliáš, 2002; Štrba, Gogoláková, 2009). In our study, within the unmanaged sites, the human impact on vegetation is largely manifested through the occurrence of synanthropic plant species, as well as on sites located on ski runs where a combination of cutting and seeding is used as the management method. Transport of sod clippings is implemented in higher elevations and on steeper slopes, and in combination with the harsh environment, the result could be the lowest species richness; nevertheless these sites have the lowest percentage of synanthropization.

Jasná Nízke Tatry ski centre has already been incorporated as the long-term part of environment in the Low Tatras National Park, where several methods of vegetation management are applied these days with varying efficiency due to the environmental factors. Regarding the management methods used in this protected area, several questions remain to see the overall impact on the whole ecosystem (changes in vegetation structure and phenological changes caused by using of artificial snow (Rixen et al., 2003; Wipf et al., 2005) and mechanical damage of chamaephytes from heavy equipment or sharp edges of skis (Kammer, 2002; Rixen et al., 2003; Wipf et al., 2005)). 


\section{Acknowledgements}

This contribution was supported by the project UGA VIII/31/2016 "Effect of management on diversity and quality of grasslands at the ski slopes" and the VEGA project No. 2/0051/17 "The Evaluation of Cultural Ecosystem Services in the Landscape on a Basis of Landscape-Ecological Research for the Development of Ecological Tourism Models”.

\section{References}

Argenti, G. \& Ferrari L. (2009). Plant cover evolution and naturalisation of revegetated ski runs in an Apennine ski resort (Italy). iForest: Biogeosciences and Forestry, 2, 178-182. DOI: 10.3832/ifor0511-002.

Barni, E., Freppaz, M. \& Siniscalco C. (2007). Interactions between vegetation, roots, and soil stability in restored high-altitude ski runs in the Alps. Arct. Antarct. Alp. Res., 39(1), 25-33. DOI: 10.1657/1523-0430(2007)39[25:IBVRAS]2.0.CO;2.

Behan, M.J. (1983). The suitability of commercially available grass species for revegetation of Montana ski area. J. Range Manag., 36(5), 565-567. DOI: 10.1046/j.1440-1703.1998.00249.x.

Bjedov, I., Ristić, R., Stavretović, N., Stevović, V., Radić, B. \& Todosijević M. (2011). Revegetation of ski runs in Serbia: Case studies of Mts. Stara Planina and Divičabre. Archives of Biological Sciences, 64(4), 1127-1134. DOI: 10.2298/ABS1104199S.

Bowker, J.M., English, D.B.K. \& Cordell H.K. (1999). Projections of outdoor recreation participation to 2050 in outdoor recreation in American life: A national assessment of demand and supply trends. Champaign: Sagamore Publishing.

Braun-Blanquet, J. (1964). Pflanzensoziologie. Grundzüge der vegetationskunde. New York, Wien: Springer-Verlag.

Burt, J.W. (2012). Developing restoration planting mixes for active ski slopes: A multi-site reference community approach. Environ. Manag., 49(3), 636-648. DOI: 10.1007/s00267-011-9797-y.

Cole, D.N. \& Bayfield N.G. (1993). Recreational trampling of vegetation: standard experimental procedures. Biol. Conserv., 6(3), 209-215.

Eliáš, P. (2002). Changes in flora and vegetation of high mountains - invasion of alien species (in Slovak). Oecol. Mont., 11, 38-40.

Elsasser, H. \& Messerli P. (2001). The vulnerability of the snow industry in the Swiss Alps. Mt. Res. Dev., 21(4), 335-339. DOI: 10.1659/0276-4741(2001)021[0335:TVOTSI]2.0.CO;2.

Graiss, W., Krautzer, B. \& Poetsch E.M. (2005). Evaluation of seed mixtures for montane pastures. Grassland science in Europe. In Integrating efficient grassland farming and biodiversity: Proceedings of the 13th International Occasional Symposium of the European Grassland Federation. 29-31 August 2005. Tartu, Estonia.

Halabuk, A., Gerhátová, K., Kohút, F., Ponecová, Z. \& Mojses M. (2013). Identification of season-dependent relationships between spectral vegetation indices and aboveground phytomass in alpine grassland by using field spectroscopy. Ekológia (Bratislava), 32(2), 186-196. DOI: 10.2478/eko-2013-0016.

Hennekens, S.M. \& Schaminée J.H.J. (2001). TURBO VEG, a comprehensive data base management system for vegetation data. J. Veg. Sci., 12, 589-591. DOI: 10.2307/3237010.

Isselin-Nondedeu, F. \& Bédécarrats A. (2007). Soil microtopographies shaped by plants and cattle facilitate seed bank formation on alpine ski trails. Ecological Engineering, 30, 278-285. DOI: 10.1016/j.ecoleng.2007.01.013.

IUCN (2016). The IUCN Red List of Threatened Species. Version 2016-3. <http://www.iucnredlist.org>.

Kammer, P.M. (2002). Floristic changes in subalpine grasslands after 22 years of artificial snowing. J. Nat. Conserv., 10, 109-123. DOI: 10.1078/1617-1381-00012.

Kangas, K., Tolvanen, A., Kälkäjä, T. \& Siikamäki P. (2009). Ecological impacts of revegetation and management practices of ski slopes in Northern Finland. Environ. Manag., 44 (3): 408-419. DOI : 10.1007/s00267-009-9336-2.

Kizeková, M., Čunderlík, J. \& Hanzes L. (2008). Practical revitalization of ski slopes in Europe and in Slovakia (in Slovak). Enviromagazín, 6, 10-11.

Krautzer, B., Graiss, W., Peratoner, G., Partl, Ch., Venerus, S. \& Klung B. (2011). The influence of recultivation technique and seed mixture on erosion stability after restoration in mountain environment. Natural Hazards, 56(2), 547-557. DOI: 10.1007/ s11069-009-9491-z.

Kulhánek, O. (1989). The golden book of skiing (in Czech). Praha: Olympia.

Lacika, J. (2001). The Low Tatras, 50 hiking trails (in Slovak). Bratislava: DAJAMA.

Marhold, K. \& Čunderlíková B. (1983). Contribution to the vegetation of ski slopes in mountainous areas of Slovakia 
(in Slovak). In Študentská vedecká konferencia Prif UK 1983: zborník recenzovaných abstraktov. Bratislava: PríF UK.

Marhold, K. \& Hindák F. (1998). Checklist of non-vascular and vascular plants of Slovakia (in Slovak). Bratislava: Veda, vydavatelstvo SAV.

Midriak, R. (1983). Morphogenesis of high mountains (in Slovak). Bratislava: Veda, vydavatel'stvo SAV.

Müllerová, J., Vítková, M. \& Vítek O. (2011). The impacts of road and walking trails upon adjacent vegetation: Effects of road building materials on species composition in a nutrient poor environment. Sci. Total Environ., 409, 3839-3849. DOI: 10.1016/j.scitotenv.2011.06.056.

Nelson, C.R. \& Halpern Ch.B. (2005). Short-term effects of timber harvest and forest edges on ground-layer mosses and liverworts. Can. J. Bot., 83, 610-620. DOI: 10.7872/cryb.v35.iss2.2014.165.

Perhans, K., Appelgren, L., Jonsson, F., Nordin, U., Söderström, B. \& Gustafsson L. (2009). Retention patches as potential refugia for bryophytes and lichens in managed forest landscapes. Biol. Conserv., 142, 1125-1133. DOI: 10.1016/j.biocon.2008.12.033.

Piscová, V. (2011). Changes in vegetation of Tatras on selected areas affected by human (in Slovak). Bratislava: Veda, vydavatel'stvo SAV.

Pohl, M., Alig, D., Körner, Ch. \& Rixen Ch. (2009). Higher plant diversity enhances soil stability in disturbed alpine ecosystems. Plant Soil, 324(1-2), 91-102. DOI: 10.1007/s11104-009-9906-3.

Rixen, Ch., Stoeckli, V. \& Ammann W. (2003). Does artificial snow production affect soil and vegetation of ski pistes? A review. Perspect. Plant Ecol. Evol. Syst., 5(4), 219-230. DOI: 10.1111/j.1365-2664.2005.01011.x.

Rixen, Ch., Freppaz, M., Stoeckli, V., Huovinen, Ch., Huovinen, K. \& Wipf S. (2008). Altered snow density and chemistry change soil nitrogen mineralization and plant growth. Arct. Antarct. Alp. Res., 40(3), 568-575. DOI: 10.1657/1523-0430(07-044)[RIXEN]2.0.CO;2.

Rolando, A., Caprio, E., Rinaldi, E. \& Ellena I. (2007). The impact of high-altitude ski runs on alpine grassland bird communities. J. Appl. Ecol. 44(1), 210-219. DOI: 10.1111/j.1365-2664.2006.01253.x.

Roux-Fouillet, P., Wipf, S. \& Rixen Ch. (2011). Long-term impacts of ski piste management on alpine vegetation and soils. J. Appl. Ecol., 48, 906-915. DOI: 10.1111/j.1365-2664.2011.01964.x.

Ruth-Balaganskaya, E. \& Myllynen-Malinen K. (2000). Soil nutrient status and revegetation practices of downhill skiing areas in Finnish Lapland - a case study of Mt. Ylläs. Landsc. Urban Plann., 50(4), 259-268. DOI: 10.1016/ S0169-2046(00)00067-0.

STATSOFT, Inc. (2005). Statistica CZ (Software system for data analysis) version 7.0.

Štrba, P. \& Gogoláková A. (2009). Unusual spreading of some predominantly synanthropic plant species in high elevation in the Oravská Magura (in Slovak). Bulletin Slovenskej Botanickej Spoločnosti, 31(2), 7-15.

ter Braak, C.J.F. \& Šmilauer P. (2012). CANOCO 5 Windows release (5.00). Software for mutivariate data exploration, testing, and summarization. Wageningen: Biometris, Plant Research International.

Tichý, L. \& Holt J. (2006). JUICE, program for management, analysis and classification of ecological data. First part of the program manual. Vegetation Science Group. Brno: Masaryk University.

Turis, P. (2007). Low Tatras National Park - natural values, history and current status of the zone protection (in Slovak). Banská Bystrica: Správa Národného Parku Nízke Tatry.

Urbanska, K.M. \& Fattorini M. (2001). Seed rain in high-altitude restoration plots in Switzerland. Restor. Ecol., 8(1), 74-79.

Van den Maarel, E. (1988). Vegetation dynamics: patterns in time and space. In J. Moravec (Ed.), Fytocenologie. Praha: Academia.

Vološčuk, I. (2005). Nature and landscape protection (in Slovak). Zvolen: TU vo Zvolene.

Whinam, J. \& Chilcott N. (2003). Impacts after four years of experimental trampling on alpine/subalpine environments in Western Tasmania. J. Environ. Manag., 67, 339-351. DOI: 10.1016/S0301-4797(02)00218-9.

Wipf, S., Rixen, Ch., Fischer, M., Schmid, B. \& Stoeckli V. (2005). Effects of ski piste preparation on alpine vegetation. J. Appl. Ecol., 42(2), 306-316. DOI: 10.1111/j.1365-2664.2005.01011.x. 